\title{
RUMO AO ESTADO MODERNO: AS RAÍZES MEDIEVAIS DE ALGUNS DE SEUS ELEMENTOS FORMADORES ${ }^{1}$
}

\author{
Raquel Kritsch
}

\begin{abstract}
RESUMO
O artigo pretende apontar alguns elementos do processo de constituição do Estado moderno, entre os quais a noção de soberania, nos séculos finais do medievo. Essa nova realidade, que não se configurou ao mesmo tempo nem por um processo único em toda a Europa, apresentou algumas características comuns. Procura-se argumentar que os conflitos entre os vários atores envolvidos nesse processo foram, simultaneamente, de natureza política e jurídica, e que nessa discussão construíram-se os alicerces legais e ideológicos do poder do Estado, ao mesmo tempo em que se determinou sua extensão.
\end{abstract}

PALAVRAS-CHAVE: Estado; soberania; Direito; Teoria Política Medieval; história do pensamento político.

Friedrich Meinecke associa, em um de seus livros, a noção de maquiavelismo à de razão de Estado $^{2}$. A palavra stato pode até ter sido introduzida na literatura política por Maquiavel e talvez não haja, antes dele, quem tenha escrito de modo tão direto sobre a lógica do poder. Mas a história da noção de "razão de Estado" começa antes, bem antes, e um bom legista poderia incluíla, se a conhecesse, no atestado de óbito de Thomas Becket. A defesa de uma comunidade universal cristã na obra de Salisbury, admirador de Becket, não é somente a expressão de uma doutrina. É também a resposta a uma nova realidade: um poder secular que afirma sua jurisdição sobre um território, em oposição tanto aos poderes locais quanto às pretensões de ingerência da Igreja.

\footnotetext{
${ }^{1}$ Este artigo resume algumas das idéias desenvolvidas em Kritsch (2002). Apresentado no I Simpósio Universidade de São Paulo - Instituto Universitário de Pesquisas do Rio de Janeiro de Pós-graduação em Teoria Política, realizado na Universidade de São Paulo em setembro de 2003.

2 "It was therefore a historical necessity that the man, with whom the history of the idea of raison d'état in the modern Western world begins and from whom Machiavellism takes its name, had to be a heathen" (MEINECKE, 1984, p. 29) ["Foi, portanto, uma necessidade histórica que o homem, com quem a história da idéia de raison d'état no moderno mundo ocidental começa e de quem o maquiavelismo tira seu nome, tivesse que ser um pagão" - nota do revisor].
}

Essa nova realidade não se configurou toda ao mesmo tempo nem por um processo único em toda a Europa. O novo poder desenvolveu-se antes na Inglaterra que no continente. No caso inglês, a Coroa afirmou-se contra os barões, internamente, e, no exterior, contra a Igreja. No continente, as forças em confronto são fundamentalmente quatro: a monarquia nascente, o Império, o Papado e os poderes locais.

$\mathrm{O}$ conflito foi simultaneamente jurídico e político. Político, porque envolveu não só uma redistribuição de poder mas também a entrada de novos atores na cena política. Jurídico, porque os confrontos principais quase nunca, ou nunca, foram explicitados diretamente como problemas de poder, mas como questões de jurisdição e de legitimidade. Os novos atores foram, entre outros:

1) a troupe do Estado (rei, ministros, burocratas, juízes, coletores de impostos etc.);

2) os elementos urbanos emergentes (artesãos e suas corporações de ofício, comerciantes, prestadores de serviços etc.);

3) uma intelectualidade que, embora dividida partidariamente e, portanto, dependente quase sempre ou da Igreja ou da espada, passou a constituir um fator de poder e

4) os grupos, em geral das camadas inferiores e muitas vezes participantes de desordens e subleva- 
ções, envolvidos nos movimentos heréticos ou de oposição às doutrinas religiosas dominantes.

A luta desenvolveu-se não só no plano da ação direta como também no das idéias. Participaram da disputa juristas, teólogos e filósofos, muitas vezes pessoas com todas essas qualificações. A eles competia determinar os fundamentos do direito de cada parte e, portanto, a legitimidade das pretensões em conflito. Nessa discussão construíram-se os alicerces legais e ideológicos do poder do Estado, ao mesmo tempo em que se determinou sua extensão.

Os conflitos só apareceram, é óbvio, quando um novo poder teve peso suficiente para questionar a ordem dada em um certo momento. Esse é o fato político em sua versão mais crua. Mas esse novo poder tentou afirmar-se não apenas pela força: seu objetivo era ser reconhecido como portador de um direito ou, mais precisamente, como legítimo detentor de uma jurisdição. Esse é o fato jurídico em sua descrição mais simples. Todavia, não houve, historicamente, nesse caso, um fato apenas político ou apenas jurídico: o político manifestase freqüentemente com a forma de uma reivindicação legal. Nesse período, o teórico político tinha de ser um jurista ou de enfrentar questões de jurisprudência. Quando Maquiavel escreveu, não precisou cuidar de questões legais (ele referia-se já à lei como um dado político e social). O trabalho de construção já tinha sido realizado: o Estado, como entidade juridicamente definida, era um fato plenamente desenvolvido, não uma novidade 3 .

A partir de que momento, então, pode-se falar em Estado em sentido compatível com a noção moderna? A palavra "compatível", nesse caso, é uma restrição importante. Trata-se de saber não a data de nascimento do Estado moderno, seja qual for a sua descrição tipológica, mas de identificar um movimento histórico bem determinado. Esse movimento ocorre segundo ritmos diferentes em diferentes locais (na Inglaterra e no continente, para tomar uma distinção bem visível) e os arranjos de poder não se dão da mesma forma em toda parte. No entanto, é possível mostrar, em todos os casos,

3 Justamente porque se pretende tratar do processo de constituição do Estado moderno, não serão abordadas no breve espaço deste artigo as formulações dos autores modernos cujos vigorosos textos passaram a fazer parte dos grandes cânones do pensamento político no Ocidente moderno. características comuns de um processo de reordenação política. Essa reordenação é constitutiva do que hoje chamamos "Estado". A ordem gestada por esse processo é o que aqui se designa como "compatível com a noção moderna".

Quais seriam, então, os elementos principais desse processo de reordenação política? Para responder à questão, adotar-se-á aqui a perspectiva genética, compartilhada por autores como Strayer (s/d), Ullmann (1965) e Gierke (1938). Strayer, em seu livro já clássico, concentrou a atenção principalmente no desenvolvimento institucional do Estado moderno, a partir da Idade Média, enquanto Ullmann enfatizou as idéias que refletiram e nortearam as mudanças políticas. De modo geral, seus trabalhos tendem a ser complementares e serão explorados a partir dessa perspectiva.

Strayer indicou três condições essenciais à constituição do Estado a partir das formações medievais: 1) o aparecimento de unidades políticas persistentes no tempo e geograficamente estáveis; 2) o desenvolvimento de instituições duradouras e impessoais; 3) o surgimento de um consenso quanto à necessidade de uma autoridade suprema e a aceitação dessa autoridade como objeto da lealdade básica dos súditos (cf. STRAYER, s/d, p. 16ss.).

Segundo Strayer, os estados europeus surgidos depois de 1100 combinaram com êxito certas características dos impérios antigos, como a vastidão e o poder, e das cidades-Estado, marcadas por um razoável grau de integração entre os súditos e por um sentimento de identidade comum. Por volta do ano 1000, depois de grandes migrações, guerras múltiplas e intensa fragmentação do poder, ainda seria difícil encontrar, na Europa, algo parecido com um "Estado".

A partir do final do século XI, porém, novas condições começaram a marcar a vida política e social. Strayer apontou em primeiro lugar a difusão do cristianismo: "a Europa ocidental só passou a ser realmente cristã nos finais do século X", escreve. A Igreja não só tinha alguns dos atributos do Estado, como instituições duradouras e uma teoria do "poder supremo" papal ${ }^{4}$, mas, além disso,

\footnotetext{
4 Vale a pena ressaltar aqui um ponto: Strayer chamou a atenção para o fato de que tais instituições impessoais e duradouras, que constituiriam um dos principais pilares do Estado moderno, foram de certo modo herdadas pelos estados nascentes do "aparato burocrático" já desenvolvido havia séculos pela Igreja. Esta, por sua vez, tivera por modelo as
} 
influenciava diretamente a política secular, pelo envolvimento do clero nos negócios públicos e pela atribuição, aos governantes, da obrigação de garantir a paz e a justiça entre os súditos. Exigências desse tipo impunham o desenvolvimento de instituições judiciais e administrativas.

O segundo fator indicado por Strayer é a estabilização da Europa, depois de longo período de migrações, invasões e conquistas. "Essa crescente estabilidade política veio dar lugar ao aparecimento de uma das condições essenciais para a constituição do Estado, a continuidade no tempo e no espaço. Pelo simples fato de manterem-se de pé, alguns reinos e principados começaram a adquirir solidez. Certos povos, ocupando determinadas áreas, permaneceram, durante séculos, integrados em um mesmo conjunto político. [...] E os governantes de reinos e principados que se mantinham no espaço e no tempo tinham oportunidades e incentivos para desenvolver instituições permanentes" (idem, p. 21-22).

Com a estabilização, surgiram condições para a implantação de padrões mais sólidos de segurança interna e externa, fundados em instituições judiciais e financeiras mais eficazes, mais complexas e crescentemente centralizadas $^{5}$. As atribuições públicas tenderam a especializar-se e, portanto, a diferenciar-se das funções costumeiras da comunidade.

instituições do Império Romano, que conheceu seu fim no século V, com a conquista de Roma. Nas palavras de Strayer: “A Igreja já tinha muitos dos atributos de um Estado instituições duradouras [como o próprio Papado], por exemplo - e estava a desenvolver outros - por exemplo, uma teoria da soberania papal" (STRAYER, s/d, p. 21). Essa observação já fôra feita por Ullmann, em seu estudo clássico (cf. ULLMANN, 1955, cap. IX e XIII).

5 Strayer lembrou que "é difícil criar instituições impessoais permanentes sem se poder dispor de arquivos escritos e de documentos oficiais. De fato, o documento escrito constitui a melhor garantia de perdurabilidade e o melhor isolador entre um administrador e as pressões pessoais" (STRAYER, s/d, p. 29). Por isso, foi relevante ainda para a consolidação dessas instituições impessoais e duradouras não apenas o surgimento de uma camada de homens instruídos, a partir do século XII, como também a recuperação de documentos legais que tinham sido a base do antigo Direito Romano - como, por exemplo, o Corpus Iuris Civilis, compilado por Justiniano, entre outros -, e que passaram então a constituir a principal referência dos novos profissionais do Direito -, os juristas civilistas, geralmente a serviço do poder temporal, fosse do Império fosse da Coroa.
Foram transformações lentas, acompanhadas e reforçadas pelo aumento da produção agrícola, do comércio e das atividades urbanas ${ }^{6}$. No final do século XIII, segundo Strayer, a terceira condição estaria consolidada, com os sentimentos de lealdade em relação à Igreja, à comunidade e à família ultrapassados pelo sentimento de lealdade ao Estado nascente, principalmente na Inglaterra.

Não que as lealdades e interesses anteriormente dominantes tivessem desaparecido ou perdido importância. $\mathrm{O}$ fato significativo é que se passou a pensar dentro de um novo quadro de referências. Esse quadro impôs-se mesmo nas rebeliões: não se lutava mais contra o Estado ou contra a instituição materializada no governo central, porém sim para mudar os padrões de governo e para obter dos tribunais a proteção desejada.

A mudança foi mais veloz na Inglaterra do que no continente. A França foi o primeiro Estado continental a constituir-se a partir de províncias virtualmente independentes e com instituições muito diferenciadas. A administração da justiça e a das finanças apareceram como fatores essenciais à formação do Estado. Os reis da França, porém, procederam com lentidão maior que os ingleses, construindo instituições mais simples e formalizando menos as funções públicas. A burocratização cresceu, porém, a partir do século XIII, como resposta às necessidades de controle das províncias anexadas. Strayer descreveu a França como um "Estado-mosaico", formado por muitas peças, com a burocracia exercendo a função de cimento (idem, p. 57).

Se essas mudanças ocorreram a partir da estabilização da Europa, o seu desenvolvimento, no entanto, não foi pacífico. O conflito, como lembra Francesco Calasso, nem sempre assumiu a forma de contestação aberta, pelos reis, da concepção tradicional da comunidade cristã universal (CALASSO, 1965, p. 232ss.). Tampouco se manifestou sempre como negação da autoridade impe-

\footnotetext{
6 Para uma abordagem mais aprofundada das transformações econômicas e sociais ocorridas na Europa entre os séculos XI e XIII, pode-se consultar, entre outros, Duby (1987, v. I, livro II), Le Goff (1965, partes I e II) e Thrupp (1988).
} 
rial. Nem era preciso. No século XIII, o poder efetivo do imperador pouco significava nos principais reinos em formação e a Igreja encarregavase de pôr em xeque esse poder sempre que podia.

É a descrição desse processo, portanto, que legitima a pretensão de falar em "Estado" em fins da Idade Média. Como escreveu Calasso: "Não tenhamos medo de fazer mau uso da palavra Estado para esses séculos que não a conheceram" (idem, p. 237). Não se trata somente de afastar aqui, como inútil, o escrúpulo defendido, por exemplo, por Hermann Heller (1987, p. 141ss.). Muito mais do que isso: trata-se de dar a ênfase necessária ao movimento da história, sem se deixar limitar por uma classificação tipológica.

O problema, como Calasso definiu-o, é entender uma realidade que se constituiu à sombra da ideologia da communitas humanitatis do Império e da Igreja. A unidade dessa communitas expressava-se no aforismo extra ecclesiam non est imperium, porque fora da Igreja não existe poder ordenado por Deus. Historicamente, no entanto, imperadores e papas disputaram, às vezes com muito sangue vertido, o poder em todas as suas formas, temporais e espirituais. Também essa disputa serviu para fecundar o pensamento político e jurídico, especialmente entre os séculos XII e XIV, mas dela não resultou, senão de maneira indireta, a destruição da idéia de uma comunidade universal dos cristãos.

Essa noção estava muito firme, como objeto de fé, no tempo do "fatigoso nascimento dos assim chamados Estados nacionais", lembrou Calasso, ao relacionar, em uma longa lista, as unidades políticas em formação em toda a Europa desde, pelo menos, o século XII: "Na Península Ibérica, depois da vitória definitiva das armas cristãs sobre os muçulmanos, nascem o reino de Aragão e o de Portugal; consolidaram-se como estados fortes, mas por meio de uma história inteiramente diversa, o reino de França e o de Inglaterra - o primeiro, com a pressão da monarquia sobre as classes feudais e por meio da exaltação do elemento citadino; o segundo, com a aliança triunfante das várias camadas sociais contra a monarquia -; no coração da Europa, o reino da Alemanha, com a prevalência dos grandes feudatários, acentuou cada vez mais uma política nacionalista, enquanto um novo Estado dele destacou-se, a Áustria; ao Norte, afirmaram-se os estados escandinavos, com predomínio do reino da Dinamarca; surgiram os reinos da Lituânia, da Polônia, da Rússia; enquanto ao Sul a Hungria, a Sérvia, a Croácia, a Bulgária, a Romênia, a Albânia consolidaram-se como estados. Eram ordenamentos políticos novos ou em renovação, que se ergueram sobre um fundo turbulento de lutas gigantescas, em que os povos europeus empenharam-se freqüentemente contra forças extra-européias (dos muçulmanos no Sul aos mongóis no Leste). E, como organismos jovens, não queriam sentir-se ligados pelas amarras de ideologias tradicionais, embora, note-se bem, como estados cristãos, vinculados à Igreja de Roma, não podiam, pela estrutura mesma do mundo medieval, ignorá-las" (CALASSO, 1965, p. 243).

Mas não apenas os elementos institucionais apontados por Strayer - a definição de fronteiras geográficas estáveis, o surgimento de instituições impessoais e burocratizadas (Fisco, Tribunais etc.) - seriam de grande relevância para a formação do Estado moderno. Seu processo de constituição incluiu também elementos de tipo ideológico, como, por exemplo, a concentração no Estado do sentimento de lealdade básica dos súditos, como apontou o autor.

Outro desses elementos ideológicos constitutivos do Estado moderno é a noção de "soberania", que também se encontrava em processo de gestação. Essa idéia começou a desenvolver-se a partir dos intermináveis conflitos de jurisdição entre papas, reis e imperadores, que dominaram os séculos finais do medievo.

Essa noção nascente de soberania tornar-se-ia em muito pouco tempo o atributo definidor do Estado moderno - mais tarde intercambiavelmente denominado Estado territorial soberano, ou simplesmente Estado soberano. Isto é, a idéia de soberania passaria a estar indissoluvelmente vinculada àquele Estado cuja característica é ser o detentor da jurisdição exclusiva sobre um determinado território, como formulariam os pensadores políticos modernos.

Essa noção nascente de soberania, por sua vez, é constituída de elementos formadores não menos relevantes, que terminariam por fazer parte dos alicerces legais e ideológicos do moderno Estado. Um desses elementos formadores é a recuperação, pelos juristas tanto canonistas quanto civilistas, dos antigos códigos do Direito Romano. Entre os inúmeros princípios retomados, há um de especial importância, que logo seria adaptado aos novos tempos, como observou Calasso: "Enquanto a 
Europa, particularmente entre os séculos XII e XIII, era trabalhada pelo incessante movimento dos povos que emergiam em busca de seu lugar, dentro e fora da jurisdição direta do Império Romano-germânico, no campo da ciência jurídica abria caminho um novo princípio, destinado a interpretar por séculos o mundo novo que estava por surgir. Esse princípio veio logo encerrado em uma fórmula que assim soou: rex superiorem non recognoscens in regno suo est imperator, e que significava o seguinte: 'o rei, que não reconhece nenhum outro poder acima de si, tem, no âmbito do próprio reino, os mesmos poderes que tem o imperador sobre todo o Império"” (CALASSO, 1965, p. 244).

Calasso dedicou à história dessa fórmula algumas páginas, lembrando as circunstâncias de seu emprego original. $\mathrm{O}$ uso mais remoto, provavelmente em 1208, é atribuído ao canonista inglês Alan. Na glosa de uma carta decretal do Papa Alexandre III, a respeito da distinção entre jurisdição espiritual e jurisdição civil, Alan retomou a questão da origem do poder imperial. Esse poder, segundo ele, é derivado do espiritual. Se assim não fosse, argumentava, o Imperador não seria responsável perante o Papa, que o julgava e o depunha.

Mas em seguida aparece um acréscimo surpreendente: "E o que se diz do Imperador deve ser dito também de qualquer rei ou príncipe não subordinado a ninguém [qui nulli subest], que tem tanto direito em seu reino quanto o Imperador no Império" (CALASSO, 1965, p. 245). A referência ao poder do Rei aparece, portanto, por analogia e não como resposta a uma questão direta.

Outra fonte mencionada por Calasso é o célebre glosador civilista Azzone, que, em uma discussão com seus alunos na Universidade de Bolonha, afirmou: "[o rei] que hoje vemos ter na sua terra o mesmo poder que o imperador [na dele], pode, portanto, fazer o que lhe agrade" (idem, p. 246). Calasso chamou atenção para a "surpreendente coincidência" temporal e para o fato de serem ambos líderes da Escola de Bolonha.

Além disso, acentuou que, ao tomar como objeto de discussão escolar um fato político ainda fresco na memória de todos - a sucessão inglesa -, ele dava como bem conhecido em seu tempo, ao usar o advérbio "hoje", "que cada rei tivesse na própria terra o mesmo poder que o Imperador na dele". Daí se deduz, acrescentou Calasso, "que essa doutrina era familiar na Escola de Bolonha, forja de todas as doutrinas jurídicas da época e, particularmente nos anos de seu maior esplendor, centro de expansão para toda a Europa" (idem, p. 256).

A partir daí, Calasso reconstituiu, embora sumariamente, os passos pelos quais, no dia-adia da política e na maturação das novas idéias pelos juristas, formou-se a concepção daquela ratio specifica do Estado, "resumida por nós, modernos, na palavra soberania" (ibidem).

Não menos relevante que os desenvolvimentos levados a cabo pelos juristas canonistas e civilistas foi - para o avanço desse processo que culminaria na consolidação do Estado moderno - o aparecimento de estudiosos dos costumes. A produção de trabalhos como os de Henry de Bracton na Inglaterra e Philippe de Beaumanoir na França indicavam mais do que um novo interesse teórico. Eles contemplavam o Direito Costumeiro, isto é, a variedade a partir do ponto de vista da unidade política e legal - a unidade do reino. Eram, em geral, profissionais treinados no Direito Romano e recrutados para o serviço da Coroa.

Quando Bracton escreveu De legibus et consuetudinibus Anglice, entre 1220 e 1230, o poder já estava centralizado, na Inglaterra. A questão não era, mais, a afirmação da supremacia real. O jurista inglês manteve a concepção do príncipe como subordinado à lei ("lex facit regem"). Na obra, há uma definição legal das funções e da autoridade reais e, embora o rei não tivesse par no seu reino, seu poder era constitucionalmente limitado. Há entre lei e rei uma relação de mútua dependência: "attribuat rex legi, quod lex attribuit ei, videlicet dominationem et potestatem" (BRACTON, 1925, p. 33$)^{7}$.

Para governar de modo reto, nos tempos de paz e de guerra, escrevia o jurista no início de seu livro, o rei necessitava de duas coisas, "a saber, arma e leis". Leis, para ele, são não somente as normas escritas, mas também os costumes que, apesar de não escritos, são legitimados pelo uso ${ }^{8}$. O costume, porém, seria corretamente chamado lei quando aprovado pelo consenso dos poderes

\footnotetext{
7 "Assim, atribua o rei à lei aquilo que a lei lhe atribui, a saber, dominação e poder" (tradução da autora).

8 "In ea quidem ex non scripto ius venit quod usus comprobavit" (BRACTON, 1925, p. 19).
} 
do Estado ou quando anteriormente definido como justo pelo príncipe. Essa ressalva estabelecia uma relação bipolar entre a função de governo e a "base" social. O uso é fonte da lei, mas a lei é a norma reconhecida como tal pelas instituições do Estado (Rei publicae). Hobbes desequilibraria aquela relação bipolar, pondo toda a ênfase no reconhecimento como marca da soberania.

A ênfase na legalidade faz da obra de Henry de Bracton uma referência fácil para o liberalismo e, mais geralmente, para o pensamento constitucionalista. Locke mencionou o jurista medieval ao discutir as circunstâncias que justificavam a resistência ao governo, no capítulo em que tratava da dissolução do governo (cf. LOCKE, 2001, p. 598). O que interessa ressaltar, neste momento, no entanto, é a idéia de unidade política em contraste com a diversidade dos costumes. Usos diferentes ganham um caráter comum como "leges Anglicance". O elemento unificador é a instituição. Uma única ordem jurídica engloba a Coroa, as funções públicas e os costumes.

Também na França, no século XIII, a reflexão sobre o Direito Costumeiro acompanhou a afirmação do poder central. A Coroa não se opunha ao costume; continuava a respeitá-lo. Normas locais ainda seriam mantidas em vigor durante séculos. Mas a corte real assumiu, com amplitude crescente, o papel de última instância judicial e, quando necessário, o de fonte primária da lei.

Um dos aspectos mais importantes do trabalho de Beaumanoir foi o do exame das competências. No condado de Clermont, onde ele era juiz, os senhores feudais tinham a jurisdição imediata. Acima desse nível estava a justiça do conde. Em vários casos podia-se passar do nível local ao do condado: apelo por falta de direito, por falso julgamento, por petição de um nobre, por tratar-se de assunto de interesse do rei, do conde ou do próprio juiz ou por tratar-se de questões relativas a tréguas (cf. BEAUMANOIR, 1970, vol. 2, §§ 295308). A jurisdição final era a do rei, pois "o rei é soberano acima de todos" (idem, § 1043). Também aqui o rei aparecia como o detentor último da jurisdição em seu reino.

Importa chamar a atenção ainda para um outro aspecto: o problema do fundamento da autoridade. A maior parte dos debates a respeito dos poderes dos reis, do Papa e do Imperador girava em torno de uns poucos modelos de legitimação. Ullmann deu atenção especial a dois, por ele indicados como as teses do poder ascendente e do poder descendente (cf. ULLMANN, 1965, p. 12). Essas teses básicas apareciam, nas discussões, combinadas com outros critérios, como o da anterioridade histórica do governo secular ou do governo eclesiástico. As duas doutrinas básicas coexistiram, com predominância de uma ou de outra, segundo a época.

A teoria do poder ascendente é a mais antiga. Afirma ser o povo, ou a comunidade, a fonte do poder. Ullmann, citando Tácito, lembra ter sido baseada nessa idéia a forma de governo das tribos germânicas. O povo elegia chefes para a guerra e para outras funções públicas e o líder tinha apenas o poder concedido pela assembléia eleitoral. Era considerado representante da comunidade e responsável perante a assembléia popular. Como conseqüência, existia um direito de resistência ao governante. Isso explica a facilidade com que se depunha e afastava-se um rei, se, na opinião do povo, tivesse deixado de representar sua vontade?

Segundo a concepção oposta, o poder residiria originalmente não no povo, como na teoria ascendente, porém sim em um ser supremo, identificado pelo cristianismo com a divindade. "Não há maior poder que o de Deus", disse São Paulo. Daí a conclusão: todo poder na terra só pode ser delegado. Até o século X, pelo menos, predominou essa doutrina. Segundo a versão aceita durante esse período, o Papa era o intermediário na transmissão do poder. Logo, a eleição pelo povo não é um requisito de legitimidade.

\footnotetext{
9 Nas palavras de Ullmann: "Metaphorically speaking power ascended from the broad base of a pyramid to its apex, the king or duke. The popular assembly controlled the ruller's government, and it was mainly as a court of law that the assembly worked effectively. This ascending theory of government may also be called the populist theory of government, because original power was anchored in the people." (ULLMANN, 1965, p. 12; sem grifo no original) ["Metaforicamente falando, o poder ascendia da larga base de uma pirâmide para o seu ápice, o Rei ou Duque. A assembléia popular controlava a gestão do governante e era principalmente como uma corte de justiça que a assembléia trabalhava efetivamente. Essa teoria ascendente do governo também pode ser chamada de teoria populista do governo, pois o poder original estava ancorado no povo" - N. R.].
} 
Egídio Romano, teólogo que escreveu no início do século XIV, por exemplo, ainda sustentava, no seu livro Sobre o poder eclesiástico (ROMANO, 1989), que a supremacia fundada nessa mediação incluía o poder de investir os governantes temporais. Ao sustentar esse ponto de vista, Egídio recuperava o agostinianismo: "Um reino que não foi instituído por meio do sacerdócio ou não foi reino, mas latrocínio, ou foi unido ao sacerdócio, pois, mesmo antes que Saul fosse instituído por Samuel, como por sacerdote de Deus, e fosse posto como Rei, Melquisedeque foi rei de Salém. Mas esse Melquisedeque, além de ser rei, era também sacerdote" (ROMANO, 1989, p. 48). A conseqüência de tudo isso é que "a autoridade régia deve estar sujeita à autoridade sacerdotal e, especialmente, à do sumo pontífice" (ibidem). O Papa é instituidor da autoridade temporal e juiz de tudo e só tem de ser julgado por Deus.

Todavia, o Papa, como detentor do poder supremo, jamais é um indivíduo: esse poder é um atributo do cargo. "Mas, como o ser e a denominação da coisa vêm principalmente da forma e não da matéria", afirmava Egídio remetendo-se aos gregos, "o povo é sempre o mesmo, o rio é sempre o mesmo, embora nem sempre os homens e a água sejam os mesmos. Assim também o sumo pontífice é sempre o mesmo, embora nem sempre seja o mesmo homem que está constituído neste ofício" (idem, p. 87). A força vinculante das decisões papais provinha não dos atributos individuais do pontífice, mas da autoridade recebida de Deus.

A fórmula evangélica da sagração de São Pedro ("tudo que ligares na terra será ligado no céu, tudo que desligares na terra será desligado no céu") foi invocada, mais uma vez, para afirmar a jurisdição tanto religiosa quanto secular da Santa Sé. Retomando opiniões de Carlyle e Scholz, Luís A. de Boni observou, na introdução ao livro de Romano, que, "sob vestes antigas", o autor compunha "uma nova teoria do poder" e o "primeiro tratado completo sobre o absolutismo" renascentista (idem, p. 13, 25).

Essa doutrina do poder descendente, porém, teve mais de uma versão. Em rigor, a idéia de Deus como fonte do poder é funcional para qualquer das pretensões políticas em jogo na Idade Média, especialmente a partir do século XIII:

1) na versão tradicional, mais útil aos papas, o sucessor de São Pedro seria o transmissor da autoridade concedida por Deus. Esse é o sentido da sagração dos governantes seculares pelo Papa, como defendia Egídio Romano;

2) em uma versão alternativa, o poder seria concedido por Deus diretamente aos governantes. Essa doutrina será a base teológica do absolutismo nos séculos XVI e XVII, mas derivava, claramente, das pretensões dos imperadores: é, por exemplo, o argumento de Frederico II, entre outros, e

3) em uma terceira interpretação, o poder seria concedido por Deus ao povo e deste aos reis ou imperadores ${ }^{10}$. Essa doutrina, de inspiração tomista, foi retomada por autores do século XIV e reapareceu, nos séculos XVI e XVII, como uma das armas do clero contra os monarcas absolutos, depois da Reforma. Foi a noção sustentada, por exemplo, por autores como Bellarmino e Suarez e contestada por Filmer.

10 Embora essa versão possa lembrar a teoria ascendente, trata-se de fato de uma versão da teoria descendente, já que a origem do poder não é o povo e sim um ser divino "acima dos homens". Como explicou Ullmann, "here [na teoria descendente] original power was located in a supreme being which, because of the prevailing Christian ideas, came to be seen as divinity itself. [...] Whatever power was found 'below', was derived from 'above', for, as St Paul said, 'There is no power but of God'. Here one can speak only on delegated power. [...] Within this thesis the people had no power other than that it had been given 'from above'. [...] The supreme officer was responsible to God alone" (ULLMANN, 1965, p. 13; sem grifos no original) ["Aqui [na teoria descendente] o poder original localizava-se em um ser supremo que, devido às idéias cristãs prevalecentes, passou a ser visto como a própria divindade. [...] Qualquer que fosse o poder, era encontrado 'abaixo de', era derivado 'de cima', pois, como dissera S. Paulo, 'Não há poder exceto o de Deus'. Aqui só se pode falar de 'poder delegado'[...]. De acordo com essa tese, o povo não tem outro poder senão aquele que foi dado 'de cima'. [...]. O governante supremo era responsável somente diante de Deus" - N. R.].

Ou seja, o que a caracteriza como descendente é o fato do poder ser delegado aos homens por Deus, causa primeira e universal de todas as coisas e autor da natureza humana. $\mathrm{O}$ povo, enquanto comunidade, é a sede da soberania. Mas para tornar-se uma comunidade política, em sentido próprio, o povo faz uma translatio potestatis, isto é, transfere voluntária e imediatamente esse poder a um príncipe, que atualiza o poder da comunidade e confere-lhe unidade política. Com isso, o povo passa a sujeitar-se ao soberano e só pode resistir a ele, de direito, quando esse soberano tornar-se um tirano, transgredindo os fins da comunidade política - fins conhecidos por todos os governantes cristãos e respeitadores da fé. Nesse caso, o Sumo Pontífice pode liberar os súditos de seu dever de obediência e declarar o soberano tirânico. Para essa versão, conferir, por exemplo, Suárez (1856-1878, tomo 24, III, 2, 1 e 17; III, 5, 2). Cf. Bellarmin (1949, cap. 5). 
A maioria dos conflitos de legitimidade, portanto, pode ocorrer sem necessidade de recurso a uma teoria ascendente pura, que faça do povo a fonte absoluta do poder. É mais funcional, ideologicamente, contestar as pretensões do Papado sem negar a noção de Deus como fonte original do poder. No fundo, a grande questão era identificar o intermediário, o comissário do Senhor.

Os grandes confrontos políticos entre papas, imperadores e reis diziam respeito não só à definição de áreas de influência e à divisão de funções, como também ao poder de legislar. Durante a maior parte da Idade Média, a fonte da lei não foi objeto de discussão. Deus é o legislador, o Papa é seu representante e ao poder temporal nada resta além de conduzir os assuntos humanos de acordo com as normas divinas. De certo modo, a lei era um dado. Mais precisamente: as grandes linhas da legislação apareciam como dadas, mas o Papa resolve as questões emergentes de acordo com critérios pragmáticos e dentro do horizonte dos interesses imediatos.

Enquanto esse ponto de vista prevaleceu, não houve conflito sobre as fontes das normas e, portanto, de jurisdição. Ressalve-se: esta é uma descrição sumária. Disputas de jurisdição existiram desde o início da Igreja e dentro da própria Igreja. O triunfo de Roma sobre a Igreja do Oriente foi o primeiro exemplo. Mas a amplitude e a importância dos confrontos a partir do século XI foram imensamente maiores, porque o cenário não era o mesmo (a Europa estabilizara-se), havia novos atores em cena (poderes regionais em busca de consolidação) e os valores em disputa eram diferentes.

Os novos conflitos, principalmente a partir da questão das investiduras, deram origem a uma extensa literatura jurídica, política e artística. $\mathrm{O}$ apogeu desse movimento ocorreu nos séculos XIII e XIV. Grande parte da produção, talvez a mais conhecida, trata do debate dos poderes do Papado e do Império. Curiosamente, alguns dos textos mais notáveis apareceram quando o Império já pouco significava. No século XIV, quando entraram no debate figuras como Guilherme de Ockham e Marsílio de Pádua, a influência do Imperador era muito limitada e o poder dos reis, em contraste, cada dia mais sólido. É como se os confrontos entre Papado e Império compusessem o cenário para a consagração de um novo poder, o do Estado moderno.
Em alguns dos textos mais ricos do século XIV, o poder real aparecia como um dado, enquanto o do Imperador e o do Papa eram objetos de discussão. Bom exemplo é o capítulo final do Brevilóquio sobre o principado tirânico, de Guilherme de Ockham. Nessa passagem, o não reconhecimento pelos reis de França de nenhum superior em assuntos temporais é mencionado como um argumento, isto é, como um fato fora de disputa e reconhecido pela própria Igreja (cf. OCKHAM, 1988, p. 184). O assunto em debate era outro: a pretensão do Papa de estender seus poderes sobre o Imperador.

Faltava pouco, nesse momento, para a pulverização da idéia de comunidade cristã universal. Como indicou Francesco Calasso, essa noção manteve-se sobretudo como uma moldura ideológica do debate político - moldura, porém, cada vez menos importante. Todavia, o poder real, muito mais concreto que o imperial no século XIV, só se consolidou por meio de uma história de disputas com a Igreja e com o Império, em que os reis enfrentaram cada adversário separadamente.

No caso inglês, o confronto com o Império foi desnecessário. Restava, como rival, o poder do clero. Quando Henrique II resolveu intervir no foro eclesiástico, a lealdade dos homens influentes estava definida. Thomas Becket só aceitou a decisão do Parlamento de Westminster com uma restrição: "salvo ordine nostro et iure Ecclesice". Henrique II recuou, por um momento, e em seguida o Parlamento especificou, em 16 artigos, as restrições. Becket aceitou, mudou de idéia e fugiu para a França.

Significativamente, partiu do Papa, Alexandre III, a tentativa de entendimento. A resistência de Becket acabou quase à margem da política pontifícia oficial. Ao reconciliar-se com Henrique II, ele manteve a cláusula: "salvo honore Dei". O rei, aparentemente, dispôs-se à convivência. Historiadores descreveram o assassínio do Arcebispo quase como um mal-entendido ou fruto de intriga. Henrique II, incitado por intrigantes, teria deixado escapar a frase famosa: "Não há ninguém capaz de vingar a honra do rei contra esse sacerdote?".

Quatro cavaleiros decidiram executar o serviço. A morte de Becket, no templo, foi descrita por Salisbury como um martírio (SALISBURY, 1984, p. 30). O mesmo Alexandre III, que tentara a 
conciliação com Henrique II, canonizou Becket em 1173, três anos depois de sua morte. Acidente ou não, o fim da história parece lógico. O poder do rei impôs-se ao resistente e a Igreja fez da vítima um santo. Que outro desfecho seria mais emblemático? Hobbes poderia ter feito essa pergunta.

Os confrontos de Roberto da Sicília com o Imperador e de Felipe, o Belo, com o Papa são especialmente interessantes por seus desdobramentos jurídicos. A controvérsia entre o Papa Bonifácio VIII e Felipe, o Belo, começou quando o Rei francês decidiu tributar o clero. A medida foi contestada pelo Papa na bula Clericis laicos em 1296. Bonifácio declarou ilegal a taxação e proibiu o clero de pagar impostos sem expressa autorização papal. Recuou, depois, ao descobrir o apoio encontrado por Felipe, mesmo entre os padres, em torno de questões de interesse francês. A essa sucedeu uma polêmica sobre o direito da Coroa de prender e julgar um bispo acusado de traição. A crise terminou com a morte do Papa, dias depois de um grupo mandado pelo Rei ter tentado prendê-lo. A história ficou por isso mesmo e, assinalou Strayer, "os papas que se seguiram não conseguiram reavivar qualquer interesse pelo caso" (STRAYER, s/d, p. 60).

Bastaria esse desfecho para tornar esse conflito extremamente importante como episódio de afirmação do poder real. Mas a história interessa também pelo desenvolvimento do debate suscitado pela questão fiscal. A defesa das pretensões reais, lembrou Ullmann, aparece em tratados escritos por ministros do rei e por professores da Universidade de Paris - estes protegidos pelo anonimato. Um texto especialmente interessante mencionado por Ullmann é a Discussão entre um clérigo e um cavaleiro. Segundo o cavaleiro, Jesus nunca deu ao Papa os poderes por este pretendidos; sendo apenas um governante espiritual, sem domínio, não cabe ao Papa ditar leis (cf. ULLMANN, 1965, p. 156).

Em 1312, Roberto, o Sábio, resistiu às forças do Imperador Henrique VII, quando este estava em campanha na Itália. Foi, então, acusado de traição, com o argumento de haver incitado os toscanos e lombardos a rebelar-se contra as forças imperiais e a expulsar a administração germânica do Norte da Itália. O rei siciliano foi citado, recusou-se a comparecer perante o tribunal imperial de Pisa e foi condenado por crime de lesa-majestade.

Como o reino da Sicília era, nominalmente, feudo do Papado, Roberto levou o problema ao Papa, que consultou vários juristas eminentes. Em 1313, Clemente V editou o decreto papal Pastoralis cura, aderindo oficialmente ao ponto de vista, até então teórico, de que o rei é soberano em seu território e não pode ser citado ante o tribunal de nenhum outro rei nem ante o do Imperador. Como rei, não poderia cometer alta traição contra nenhum outro rei, por não ser súdito.

Esse decreto foi provavelmente a primeira expressão legal do conceito de soberania territorial. Negava a universalidade do poder do Imperador, em que o Papa sempre havia insistido com especial interesse. Segundo o decreto, o Imperador só exerceria um poder territorialmente limitado. Para muitos juristas, tanto acadêmicos - como os da Universidade de Bolonha - quanto profissionais, a idéia era bem familiar desde o século XIII.

A referência mais freqüente remete a Beaumanoir, autor do primeiro texto conhecido em que aparece a palavra "soberano" ("souverain"). A noção vinculava-se tanto à idéia de função governamental quanto à de jurisdição: "Verdade é que o rei é soberano acima de todos e tem, de seu direito, a guarda geral de todo o seu reino, pelo que ele pode estabelecer tudo que lhe aprouver para o proveito comum, e o que ele estabelece deve ser seguido [...]. E, como ele é soberano acima de todos, nós o nomeamos ao falar de alguma soberania que lhe pertença" (BEAUMANOIR, 1970, § 1043).

Todas as propriedades mais importantes do poder soberano, tais como concebidas pelas modernas teorias do Estado, aparecem nessa passagem de Beaumanoir: o domínio definido ("seu reino"); o poder legislativo amplo ("estabelecer tudo que lhe aprouver para o proveito comum"); o caráter vinculante das normas ("o que ele estabelece deve ser seguido"); o uso da força como parte da função ("a guarda geral de todo o reino"); a supremacia da autoridade ("soberano acima de todos") e, o que é especialmente significativo, a idéia de uma legitimidade independente de qualquer outro poder ("tem, de seu direito" todos os poderes e funções mencionados).

Retomando o argumento de Calasso, quando se entende esse processo formador, pode-se fazer a crítica da opinião comum que nega haver a Idade 
Média conhecido o conceito de Estado e, também, o de soberania. Segundo essa opinião, as duas idéias só se afirmaram no século XVI, com o triunfo do absolutismo, isto é, das condições de poder descritas teoricamente por Jean Bodin ${ }^{11}$.

Os tempos modernos, escreveu Calasso, preencheram a palavra "soberania" com um conteúdo que, como "fatalmente sucede às fórmulas definitórias", foi-se petrificando e assumindo o peso de um dogma, um "verbum mysticum, destinado a cobrir alguma coisa que na realidade se havia distanciado sempre mais das consciências". Fazer a história de um dogma, segundo Calasso, implica dissolvê-lo. Esse dogma a Idade Média não conheceu, por ser uma criação da Idade Moderna. Mas, ao invés, "pôs o seu problema em termos modernos e seu esforço consistiu sobretudo na consumação do velho invólucro que, como se viu, havia incubado a nova idéia"(CALASSO, 1965, p. 256-257).

Marcel David, examinando o uso das palavras "soberano" e "soberania" nos séculos XIII e XIV, pôs na mesa um argumento importante: nos séculos XII e XIII, "três das noções expressas em francês pela palavra 'soberania' já existiam, simplesmente adaptadas à estrutura da sociedade política da época. Duas delas, 'autoridade suprema' e 'recusa de toda ingerência de um superior no nível de uma potência reconhecida como legítima', exprimiamse pela mesma palavra: auctoritas. Quanto à potência pública, é a palavra latina a partir da qual ela formou-se, potestas, que habitualmente serve para exprimi-la. Assim, o pensamento político dessa época soube fazer do vocabulário um uso mais judicioso do que a partir do século XVI" (DAVID,

\footnotetext{
11 A opinião é bastante antiga, mas encontrou refinados defensores no século XX. Apareceu, por exemplo, entre outros, na abordagem de Heller e seus discípulos, que são numerosos (cf. HELLER, 1987, p. 152ss.). Com aparência mais moderna, revestida de coloração histórica, foi repetida por autores contemporâneos como Bartelson (1995, p. 90ss.).
}

1954, p. 14). Além de tudo, disse também Marcel David, "a história e a lógica não se opõem a que as idéias inerentes ao termo 'soberania' tenham sido já extraídas, simplesmente expressas no latim da época, com ajuda de um vocabulário original que pôde muito bem permanecer sem grande influência sobre aquele que utilizamos em francês" (idem, p. 17).

É a insuficiência dessa noção de processo, em sua análise, que dificulta o tratamento das noções de Estado e de soberania no capítulo de Heller sobre os pressupostos históricos do Estado atual. O texto contém referências históricas, mas permanece preso a uma perspectiva tipológica que acaba sendo dogmática. Por isso, ele acaba tratando exemplos históricos importantes, como os da Sicília e da Inglaterra, quase como casos excepcionais, desvios da norma, dados que não desmentem a communis opinio. Talvez o problema esteja no fato de que, enquanto Weber utilizou material histórico para construir um tipo, Heller, movido por uma inspiração declaradamente weberiana, tenha partido de um tipo (do Estado) e de um conceito cristalizado (o de soberania) para examinar a história política medieval.

O caminho percorrido até aqui autoriza, portanto, afirmar que a noção de gubernatio já não basta, obviamente, para dar conta dos elementos apontados nesse texto. A palavra pode continuar em uso, mas tornou-se cada vez mais pobre diante dos desenvolvimentos políticos e jurídicos ao longo dos séculos XIII a XV. Novas noções são necessárias para dar conta dos novos fatos. Seja polemizando, seja refletindo sobre o espetáculo da política, os filósofos e juristas do final da Idade Média tentaram refazer o quadro conceitual. A tarefa ganhou impulso considerável a partir da recuperação de Aristóteles por São Tomás de Aquino. Muito trabalho estava feito quando Maquiavel e Bodin produziram seus tratados sobre as questões do Estado e da soberania. Nem os teóricos anteriores trataram apenas do que deve ser, desconhecendo a "verità effetuale delle cose", nem foram cegos diante dos atributos do poder soberano.

Raquel Kritsch (kritsch@uel.br) é Doutora pela Universidade de São Paulo (USP) e Professora Adjunta do Departamento de Ciências Sociais da Universidade Estadual de Londrina (UEL). 


\section{REFERÊNCIASBIBLIOGRÁFICAS}

BARTELSON, J. 1995. A Genealogy of Sovereignty. Cambridge : Cambridge University.

BEAUMANOIR, P. 1970. Coutumes de Beauvaisis. Paris : J. Picard.

BELLARMIN, R. 1949. The Power of the Pope in Temporal Affairs, against William Barclay. Ed. by George Albert Moore. Chevy Chase : Country Dollar.

BLACK, A. 1992. Political Thought in Europe (1250-1450). Cambridge : Cambridge University.

BOÉR, N. 1972. Relação entre a Igreja e o Estado no fim do século XIII e no início do século XIV nos escritos de filósofos de Estado e de canonistas. São Paulo. Tese (Doutorado em Educação). Universidade de São Paulo.

BRACTON, H. 1925. De legibus et consuetudinibus anglice. Ed. by G. E. Woodbine. V. 1-2. New Haven : Yale University.

BURNS, J. H. (ed.). 1988. The Cambridge History of Medieval Political Thought c.350-c.1450. New York : Cambridge University.

CALASSO, F. 1954. Medioevo del diritto. V. 1-2. Milano: A. Giuffré.

1965. Gli ordinamenti giuridici del Rinascimento medievale. Milão : Giuffrè.

DAVID, M. 1954. La souveraineté et les limites juridiques du pouvoir monarchique du IXe au XVe siècle. Paris : Dalloz.

D'ENTREVES, A. P. 1980. La dottrina del diritto naturale. Milano : Comunità.

1962. La dottrina dello Stato. Torino : G. Giappichelli.

DUBY, G. 1987. Economia rural e vida no campo no Ocidente medieval. 2 v. Lisboa: ed. 70.

FINKE, H. 1964. Aus den Tagen Bonifaz VIII. Funde und Forschungen. Roma : Anastatica.

FRIEDRICH, C. J. 1964. La Filosofia del Derecho. Ciudad de México : Fondo de Cultura Económica.

GIERKE, O. 1938. Political Theories of the Middle Ages. Cambridge : Cambridge University.
GRABMANN, M. 1934. Studien über den Einfluss der Aristotelischen Philosophie auf die mittelalterlichen Theorien über das Verhältnis von Kirche und Staat. Sitzungsberichte der_Bayerischen Akademie der Wissenschaften. Philosophisch-historische Abtl. Heft 2. München : Verlag der Bayerischen Akademie der Wissenschaft.

HELLER, H. 1987. Teoria del Estado. Ciudad de México : Fondo de Cultura Económica.

HINSLEY, F. H. 1989. Sovereignty. Cambridge : Cambridge Universtiy.

HOLMES, G. 1984. A Europa na Idade Média : 1320-1450. Lisboa: Presença.

KANTOROWICZ, E. 1981. The King's Two Bodies. Princeton : Princeton University.

KEEN, M. 1991. The Penguin History of Medieval Europe. Harmondsworth : Penguin.

KRITSCH, R. 2002. Soberania : a construção de um conceito. São Paulo : Humanitas-Imprensa Oficial do Estado de São Paulo.

LE GOFF, J. 1965. Das Hochmittelalter. Col. "Universalgeschichte der XXI. Jahrhundert", v. 11. Frankfurt am Main : Fischer Bücherei.

LOCKE, J. 2001. Segundo tratado sobre o governo. São Paulo : M. Fontes.

MEINECKE, F. 1984. Machiavellism. The doctrine of "Raison d'État" and its Place in Modern History. London : Westview.

ОСКНАМ, G. 1988. Brevilóquio sobre o principado tirânico. Petrópolis : Vozes.

PÁDUA, M. 1968. Le défenseur de la paix. Org. par J. Quillet. Paris : J. Vrin.

1991. Defensor menor. Petrópolis : Vozes.

PASSOS, J. A. M. B. 1972. Bonifácio VIII e Felipe o Belo de França. São Paulo. Tese (Doutorado em História). Universidade de São Paulo.

QUIDORT, J. 1989. Sobre o poder régio e papal. Petrópolis : Vozes.

QUILLET, J. 1970. La philosophie politique de Marsile de Padoue. Paris : J. Vrin. 
ROMANO, E. 1989. Sobre o poder eclesiástico. Petrópolis : Vozes.

SALISBURY, J. 1984. Policraticus. Madrid : Nacional.

SCHMITT, C. 1988. Théologie politique. Paris : Gallimard.

STRAUSS, L. \& CROPSEY, J. (eds.). 1963. A History of Political Philosophy. Chicago : Chicago University.

STRAYER, J. s/d. As origens medievais do Estado moderno. Lisboa: Gradiva.

SUÁREZ, F. 1856-1878. Defensio fidei Catholica et Apostolicae. In : par D. M. André. Paris : L. Vivès.

THRUPP, S. L. (ed.). 1988. Change in Medieval Society. Toronto : Toronto University.
TIERNEY, B. \& LINEHAN, P. (eds.). 1980. Authority and Power. Studies on Medieval Law and Government. Cambridge : Cambridge University.

TORRES, J. C. B. 1988. Figuras do Estado moderno. São Paulo : Brasiliense.

ULLMANN, W. 1949. The Development of the Medieval Idea of Sovereignty. English Historical Review, London, v. LXIV, n. CCL, p. 1-33, Jan.

. 1955. The Growth of Papal Government in the Middle Ages. London : Methuen.

. 1965. A History of Political Thought: The Middle Ages. Harmondsworth : Penguin.

WILKS, M. 1963. The Problem of Sovereignty in the Later Middle Ages. Cambridge : Cambridge University. 